\title{
HUBUNGAN KELERENGAN DENGAN KADAR AIR TANAH, pH TANAH, DAN PENAMPILAN JERUK GERGA DI KABUPATEN LEBONG
}

\author{
Nurlina Banjarnahor ${ }^{1}$, Kanang Setyo Hindarto $^{2^{*}}$, Fahrurrozi $^{1}$ \\ ${ }^{1}$ Program Studi Agroekoteknologi, Fakultas Pertanian Universitas Bengkulu, \\ Jl. W.R. Supratman, Kandang Limun Bengkulu, 38127 \\ 2 Program Studi Ilnu Tanah, Fakultas Pertanian Universitas Bengkulu, \\ Jl. W.R. Supratman, Kandang Limun Bengkulu, 38127 \\ *Corresponding Author: setyo_hindarto@yahoo.com
}

\begin{abstract}
[RELATIONSHIP OF SLOPE STEEPNESS TO SOIL WATER CONTENT, SOIL PH, AND PERFORMANCES OF GERGA ORANGE AT LEBONG REGENCY]. In Lebong Regency, gerga orange is commonly grown in hilly areas and many of the crop stands were found on steep sloped land. Objective of this study was to determine the pattern of relationship of slope steepness to soil water content, soil $\mathrm{pH}$, and the overall plant performances. Soil samples were collected from the area below the canopy of 300 gerga orange trees differing in the slope steepness for for soil water content (SWC) and soil $\mathrm{pH}$. The observation of plant performances were also made from the same tree as used for the soil properties observations. The analysis of regression indicated that relationship of slope steepness to both the observed soil properties and plant performances could be represented by the linear models suggesting that all the observed variables were reduced along with the increasing slope steepness.
\end{abstract}

Keyword: Gerga orange, Slope steepness, soil water content, soil pH, plant performances

\begin{abstract}
ABSTRAK
Di Kabupaten Lebong, jeruk gerga umumnya dibudidayakan pada daerah berbukit dan banyak dijumpai pohon jeruk tersebut ditanam pada lahan yang curam. Tujuan penelitian ini adalah untuk menentukan bentuk hubungan kelerangan dengan dengeran kadar air tanah, $\mathrm{pH}$ tanah, dan penampilan umum tanaman jeruk. Sampel tanah untuk pengamatan kadar air tanah dan $\mathrm{pH}$ tanah dikumpulkan dari daerah di bawah kanopi dari 300 pohon jeruk yang tumbuh pada tingkat kelerengan berbeda. Pengamatan terhadap penampilan tanaman juga dilakukan terhadap pohon-pohon yang digunakan untuk pengambilan sampel tanah. Analisis regresi menunjukkan bahwa hubungan kelerengan dengan sifat tanah dan penampilan tanaman yang diamati dapat dinyatakan dalam bentuk persamaan linier yang menjelaskan bahwa sifat tanah maupun penampilan tanaman mengalami penurunan seiring dengan semakin tingginya tingkat kelerangan tanah.
\end{abstract}

Kata kunci : Jeruk Gerga Lebong, tingkat kelerangan, kadar air tanah, pH tanah, penampilan tanaman 


\section{PENDAHULUAN}

Jeruk merupakan salah satu produk pertanian yang memiliki peranan yang cukup penting dan dapat diandalkan dalam mewujudkan program pembangunan pertanian (Ibad, 2009). Produksi jeruk Indonesia pada lima tahun terakhir mengalami peningkatan $4,13 \%$ yaitu 2.028 .904 ton tahun 2010, 1.818.949 ton tahun $2011,1.611 .768$ ton tahun $2012,1.654 .732$ ton tahun 2013 dan 2.243.837 tahun 2014 (BPS, 2015). Namun peningkatan produksi ini belum memenuhi kebutuhan konsumsi jeruk Indonesia. Hal ini terbukti dari impor buah jeruk yang masuk ke Indonesia semakin tinggi setiap tahun (Badan Litbang Pertanian, 2005).

Salah satu jenis jeruk keprok yang dapat dikembangkan di Provinsi Bengkulu adalah Jeruk Gerga Lebong yang sekarang terdaftar dengan nama jeruk varietas RGL (Rimbo Gerga Lebong) (Suwantoro, 2010). Jeruk RGL termasuk jenis jeruk keprok yang berasal dari Israel yang dibawa melalui Thailand kemudian ditanam di Kabupaten Karo Sumatera Utara, dibawa dan dikembangkan oleh Bapak Gerga di Kabupaten Lebong, Provinsi Bengkulu (Supriyanto, 2011).

Jeruk RGL merupakan komoditas unggulan Kabupaten Lebong karena mempunyai keunggulan kompetitif yaitu dapat berbuah sepanjang tahun (BPTP Bengkulu, 2012). Jeruk tersebut berukuran buah besar 200-350 g dan kadar sari buah tinggi serta mempunyai potensi pasar yang baik. Jeruk RGL

Sejak tahun 2011, jeruk RGL telah ditetapkan sebagai komoditas prioritas nasional untuk dikembangkan. Namun salah satu kendala dalam pengembangan tanaman jeruk lokal ini adalah mutu hasil buah yang masih rendah. Hal ini disebabkan oleh hama penyakit tanaman dan juga karena usaha untuk menjaga kesuburan lahan yang dilakukan melalui pemupukan yang belum sesuai dengan kebutuhan tanaman (Rambe et al., 2012).

Menurut Adiwilaga (1985) untuk mendapatkan hasil yang baik secara ekonomis kegiatan pertanian harus memperhatikan syarat tumbuh tanaman, yang terkait dengan kondisi fisik lahan. Kondisi ini berkaitan dengan struktur internal (drainase dan hara tanah) dan kondisi lingkungan (iklim dan geografis). Hal ini diketahui berdasarkan pertimbangan dari tingkat potensial lahan secara fisik pada suatu wilayah, tanpa ditunjang oleh sarana ekonomi yang memadai, dan tidak banyak memberikan kontribusi terhadap pengembangan wilayah tersebut (Djaenuddin, 2003). Sedangkan menurut Sugiharto (2001), sub faktor yang dapat menjadi indikator untuk menentukan pemanfaatan lahan untuk kegiatan pertanian adalah topografi, kemiringan lereng, kondisi lapisan tanah, kemampuan lahan yang berkaitan dengan kondisi struktur tanah, pola iklim yang berkaitan dengan curah hujan, kondisi geologi, ketersediaan sumber daya air dan kerentanan terhadap bencana.

Daerah tropis secara umum dicirikan oleh keadaan iklim yang hampir seragam. Namun, dengan adanya perbedaan geografis seperti perbedaan ketinggian tempat dari atas permukaan laut (dpl) akan menimbulkan perbedaan cuaca dan iklim secara keseluruhan pada tempat tersebut. Unsur-unsur cuaca dan iklim tersebut banyak dikendalikan oleh letak lintang, ketinggian, jarak dari laut, topografi, jenis tanah dan vegetasi. Dataran tinggi banyak mempengaruhi penurunan tekanan udara dan suhu udara serta peningkatan curah hujan. Laju penurunan suhu akibat ketinggian memiliki variasi yang berbeda-beda untuk setiap tempat (Sangadji, 2001).

Penelitian tentang kesesuaian lahan untuk pertanaman jeruk RGL menjadi sangat penting karena di Provinsi Bengkulu khususnya daerah Kabupaten Lebong belum pernah dilakukan penelitian secara mendalam khususnya tentang korelasi kelerengan terhadap hasil dan produksi jeruk Gerga Lebong. Penelitian ini bertujuan untuk mendapatkan hubungan antara kelerengan dan pertumbuhan serta hasil jeruk Gerga.

\section{METODE PENELITIAN}

Penelitian ini dilaksanakan pada bulan Maret sampai Mei 2016 di lahan petani jeruk Gerga Lebong Kecamatan Rimbo Pengadang, Kabupaten Lebong. Topografi yang terdapat di lokasi bergelombang sampai berbukit dengan ketinggian $834 \mathrm{~m}$ dpl. Petakan sampel tanaman berisi tanaman jeruk yang telah berproduksi dengan luasan 1,5 ha dengan populasi tanaman \pm 300 batang jeruk Gerga. Jarak tanam yang digunakan $5 \mathrm{~m} \mathrm{x}$ $6 \mathrm{~m}$ yang ditanam secara zigzag.

Tanaman jeruk Gerga yang diteliti merupakan tanaman yang berumur \pm 5 tahun dan sudah berproduksi. Untuk kondisi tanah sudah pernah diteliti sebelumnya oleh Rambe et al. (2012) yang hasilnya menunjukkan bahwa kandungan unsur Nitrogen $(\mathrm{N})$ sangat rendah, Fosfor $(\mathrm{P})$ rendah dan Kalium $(\mathrm{K})$ sedang, dan rata-rata tingkat keasaman tanah cukup tinggi $(\mathrm{pH}=4,3)$. Pada saat penelitian digunakan beberapa alat dan bahan lapangan seperti klinometer, kompas, meteran kain, botol film, dan kantong plastik. Sedangkan alat dan bahan yang digunakan di laboratorium ilmu tanah timbangan analitik, oven, botol film sedang, tabung aluminium, batang pengaduk, tanah sampel dan aquades.Variabel yang diamati pada penelitian ini meliputi variabel 
tanah (pH tanah dan kadar air) dan tanaman (tinggi tanaman, diameter batang, jumlah buah, dan berat buah). Data peubah pengamatan dianalisis secara statistik menggunakan analisis regresi linear sederhana (Draper and Smith, 1966).

\section{HASIL DAN PEMBAHASAN}

Kecamatan Rimbo Pengadang, Kabupaten Lebong merupakan daerah pengembangan jeruk Gerga Lebong yang mempunyai topografi bergelombang sampai berbukit dengan ketinggian 500-900 m dpl. Luas wilayah Rimbo Pengadang 7300 ha. Luas pertanaman jeruk RGL (Rimbo Gerga Lebong) tahun 2010 seluas 100 ha dan direncanakan menjadi 200 ha lagi pada tahun 2016. Ketinggian lokasi sekitar $835 \mathrm{dpl}$. Keadaan iklim rata-rata harian pada siang hari antara 28-32 ${ }^{0} \mathrm{C}$ dan pada malam hari 22-25 ${ }^{\circ} \mathrm{C}$ (BPS, 2010). Tipe iklim berdasarkan Schmidt dan Ferguson mempunyai tipe iklim B dengan curah hujan 2500$4500 \mathrm{~mm} /$ tahun (BPTP Bengkulu, 2012).

Berdasarkan kondisi lahan yang ada di Kabupaten Lebong kemiringan lahan di wilayah penelitian ini bervariasi mulai dari yang datar sampai sangat curam atau mencakup lima kelas kelerengan yaitu datar (0$8 \%$ ), landai (8-15\%), bergelombang (15-25\%), curam (25-45\%), dan sangat curam (>45\%). Berdasarkan penelitian Rambe et al. (2012) menunjukkan bahwa sejak tahun 2011, jeruk RGL telah ditetapkan sebagai komoditas prioritas nasional untuk dikembangkan. Namun salah satu kendala dalam pengembangan tanaman jeruk lokal ini adalah mutu hasil buah yang masih rendah, ditandai dengan kulit buah burik, kotor, tidak mulus, warna buah tidak menarik/pucat, dan rasa buah bermacam-macam. Hal ini juga disebabkan oleh hama penyakit tanaman dan juga karena usaha untuk menjaga kesuburan lahan belum sesuai dengan kebutuhan tanaman.

Jeruk Gerga ini memiliki rasa khas, yang berbeda dengan jeruk lainnya yang ada di Indonesia. Menurut Rambe \& Ivanti (2013) dibandingkan dengan jenis jeruk keprok lainnya, jeruk RGL memiliki ukuran daun besar dan kaku serta kulit buahnya tebal. Tanaman jeruk ini menghasilkan buah dengan berat per buah 173-347 g. Kulit buah jeruk RGL berwarna kuning orange dan daging buah berwarna orange yang bercitarasa manis, asam, segar. Lebih spesifik, buah jeruk RGL memiliki karakteristik fisik di antaranya Total Padatan Terlarut (TPT) berkisar antara 12-16 Brix (BPSB).

Tanaman jeruk umumnya dapat berbuah setelah berumur 3 tahun dan buah paling banyak pada tanaman yang berumur lebih dari 5 tahun (Purnomosidhi et al.,2007). Menurut Suwantoro (2010) dan pengalaman petani, jeruk RGL sudah mulai berbuah dan bahkan bisa dipanen pada umur 2 tahun, ini salah satu keunggulan jeruk RGL yang ditanam di kabupaten Lebong Provinsi Bengkulu.

Persyaratan pertumbuhan jeruk secara umum dengan karakteristik tanah yang memiliki $\mathrm{pH}$ 5-6, dapat tumbuh baik pada lahan yang mempunyai kemiringan sampai $30^{\circ}$ dengan ketinggian 800$1.500 \mathrm{dpl}$. Di daerah tropis dan subtropis $\left(35^{\circ} \mathrm{LU}-\right.$ $35^{\circ} \mathrm{LS}$ ), dengan suhu $25-30{ }^{\circ} \mathrm{C}$, curah hujan berkisar antara 1.250-1.900 mm per tahun, kelembaban udara 70$80 \%$, dan penyinaran matahari 50-60\% (tidak menyukai tempat yang terlindung), air tanah terdapat pada kedalaman $0,5 \mathrm{~m}$ pada saat musim penghujan dan $1,5 \mathrm{~m}$ pada saat musim kemarau. Memerlukan 5-9 bulan basah (musim hujan), suplai air yang cukup diperlukan pada bulan Juli-Agustus (Prihatman, 2000). Selain itu, menurut Rambe et al. (2012) pemupukan dan pemangkasan perlu dilakukan untuk meningkatkan mutu buah jeruk seperti varietas jeruk gerga. Pemangkasan yang dilakukan adalah pemangkasan cabang,ranting/tunas yang tidak produktif dan buah yang tidak tumbuh sempurna/ kecil. Pemberian pupuk dilakukan berdasarkan hasil analisis tanah/tanaman (dolomit $450 \mathrm{~g} / \mathrm{m}^{2}$, kompos $40 \mathrm{~kg}$, Urea $240 \mathrm{~g}$ dan NPK $1200 \mathrm{~g} /$ pohon/tahun menghasilkan jumlah buah relatif lebih banyak.

Untuk mewujudkan pengembangan jeruk RGL tersebut, dilakukan pengamatan hubungan antara lereng dengan pertumbuhan (tinggi tanaman, luas kanopi, diameter batang) dan hasil tanaman (jumlah buah dan berat buah). Kabupaten Lebong termasuk daerah yang memiliki curah hujan yang tinggi yaitu rata-rata $233,75 \mathrm{~mm} /$ bulan, dengan jumlah hari hujan rata rata 14,6 hari/bulan pada musim kemarau dan 23,2 hari/bulan pada musim hujan, sehingga berpengaruh terhadap kelembaban tanah. Dengan demikian, jumlah kadar air untuk setiap kemiringan lereng akan berbedabeda. Lereng yang semakin curam memiliki kadar air yang rendah disebabkan aliran permukaan atau pergerakan air yang semakin cepat dibandingkan lereng datar, landai maupun bergelombang. Jeruk Gerga yang dibudidayakan di Kabupaten Lebong ditanam di kelas kemiringan lereng yang berbeda-beda.

Variabel-variabel yang diamati yaitu kadar air, $\mathrm{pH}$, tinggi tanaman, luas kanopi, diameter batang, jumlah buah dan berat buah yang disebut sebagai (Y), sedangkan lereng disebut sebagai (X). Nilai lereng (X) akan diregresikan terhadap hasil dan pertumbuhan (Y) jeruk Gerga Lebong. Hasil analisis regresi antara kemiringan lereng terhadap hasil dan pertumbuhan jeruk Gerga Lebong untuk masing- 
masing kelas kemiringan lereng dapat diketahui setelah melakukan analisis statistik. Untuk menentukan bentuk hubungan antara kemiringan lereng lahan, hasil dan pertumbuhan tanaman dilakukan analisis regresi linear sederhana (Draper \& Smith, 1966).

Berdasarkan hasil analisis regresi terlihat tingkat kemiringan lereng berhubungan nyata terhadap hasil tanaman seperti berat buah dan jumlah buah. Hal ini disebabkan kadar air yang tinggi, dan $\mathrm{pH}$ yang masam. Menurut Hermawan (2004) kadar air tanah yang diukur menggambarkan karakteristik air tanah yang berhubungan dengan kemampuan tanah dalam menahan air pada kondisi sangat kritis. Semakin tinggi nilai kadar air pada kondisi kering angin maka semakin besar pula kemampuan tanah dalam menyimpan air bagi tanaman ketika mengalami kekeringan seperti selama musim kemarau. Kondisi yang demikian ternyata tidak berpengaruh terhadap produksi jeruk Gerga Lebong di lahan penelitian pada kondisi lapangan sebagaimana yang selama ini telah diteliti.

Hasil analisis regresi sederhana terlihat bahwa sekitar $55,6 \%$ penurunan kadar air tanah di lahan yang diteliti berhubungan dengan kemiringan lahan sebagaimana disajikan pada Gambar 1. Kadar air cenderung turun sebanyak 0,38 \% untuk setiap 1\% kenaikan kemiringan lahan. Hal ini disebabkan lahan yang semakin curam, maka tingkat kadar air tanah akan semakin menurun.

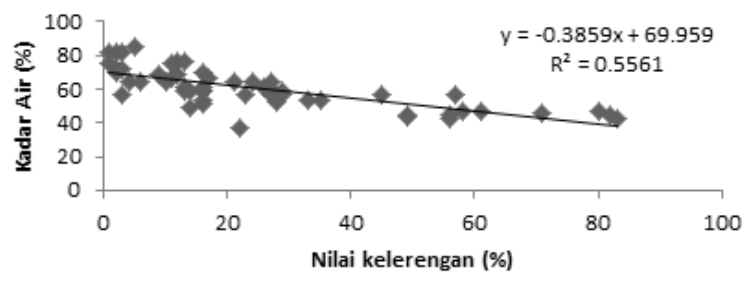

Gambar 1. Kurva nilai kelerengan (\%) dan kadar air (\%)

Terlihat pada Gambar 2 semakin meningkat kemiringan lereng akan diikuti oleh menurunnya $\mathrm{pH}$ tanah. Kontribusi nilai kelerengan sebesar 7,4\% terhadap keragaman $\mathrm{pH}$ tanah. Di samping itu terdapat kecenderungan penurunan $\mathrm{pH}$ tanah rata-rata sebesar 0,003 unit pada setiap persen kenaikan nilai kelerengan.

Penggerusan tanah oleh air pada daerah berlereng juga mengakibatkan tanah mulai terkikis dan terangkut, pada akhirnya meninggalkan tanah yang kurang subur sehingga produktivitas tanah dan tanaman menurun. Penggunaan lahan mempengaruhi besarnya kandungan C-organik, nitrogen, fosfor, kapasitas tukar kation, permeabilitas, porositas dan infiltrasi (SanchezMaranon et al., 2002). Pernyataan tersebut sejalan dengan hasil penelitian Yusrial \& Wisnubroto, (2004), yang menunjukkan bahwa pada lahan yang berkemiringan tinggi terjadi penurunan bahan organik, permeabilitas dan porositas tanah. Dengan demikian, $\mathrm{pH}$ tanah juga akan mengalami penurunan dengan semakin tinggi tingkat kemiringan lereng.

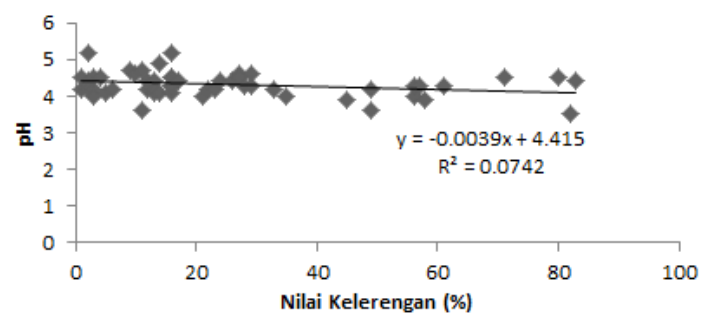

Gambar 2. Kurva nilai kelerengan (\%) dan pH

Pada Gambar 3 terlihat bahwa semakin meningkat nilai kelerengan akan diikuti oleh turunnya tinggi tanaman. Kontribusi nilai kelerengan terhadap tinggi tanaman sebesar 1,8\% Tinggi tanaman cenderung turun sebanyak $0,25 \mathrm{~cm}$ untuk setiap $1 \%$ kenaikan kemiringan lahan.

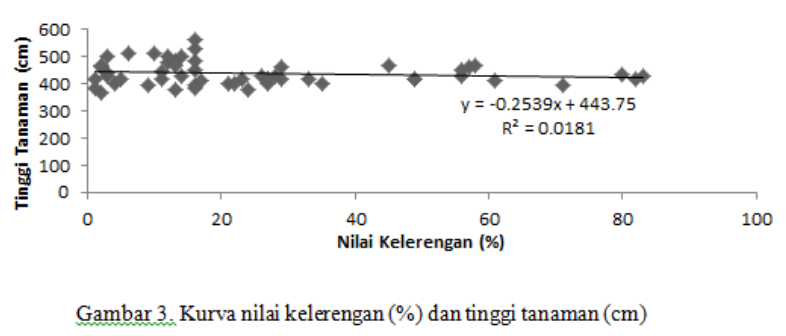

Apabila terjadi erosi maka akan menimbulkan run off (aliran permukaan) yang tinggi dan infiltrasi rendah yang menyebabkan tanaman sulit menyerap air. Menurut Morgan (1979), vegetasi berperan penting dalam melindungi tanah dari erosi. Keefektifan vegetasi dalam menekan aliran permukaan dan erosi dipengaruhi oleh tinggi tajuk, luas tajuk, kerapatan vegetasi, dan kerapatan perakaran. Lahan dengan kemiringan tinggi rentan terhadap erosi yang antara lain diakibatkan rendahnya stabilitas agregat. Hasil penelitian Murcitro et al. (2005) menunjukkan bahwa tanah dengan agregat yang stabil akan memiliki nilai berat volume yang rendah dengan porositas dan nilai karbon organik yang lebih tinggi. Oleh karena itu wajar jika peningkatan kemiringan lahan akan diikuti semakin menurunnya keragaan tanaman.

Luas kanopi pada setiap kelas kemiringan lereng menunjukkan bahwa semakin naik atau semakin curam kemiringan lereng maka luas kanopi jeruk Gerga Lebong cenderung menurun. Hasil analisis regresi 
menunjukkan bahwa kontribusi nilai kelerengan terhadap keragaman luas kanopi sebesar 10,6\%. Luas kanopi cenderung turun sebanyak $0,78 \mathrm{~cm}^{2}$ untuk setiap 1\% kenaikan kemiringan lahan (Gambar 4)

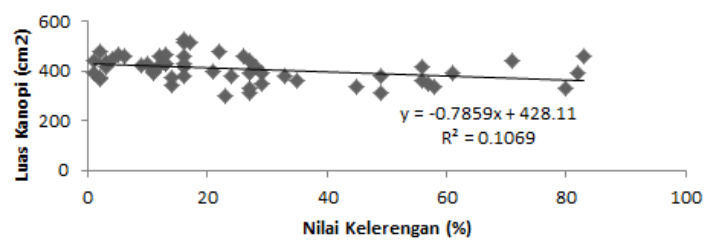

Gambar 4. Kurva nilai kelerengan (\%) dan luas kanopi $\left(\mathrm{cm}^{2}\right)$

Diameter batang pada kelas kemiringan lereng menunjukkan bahwa semakin meningkat nilai kelerengan maka diameter batang semakin kecil. Sekitar $13 \%$ keragaman diameter batang di lahan yang diteliti dijelaskan oleh kemiringan lahan (Gambar 5). Diameter batang cenderung turun sebanyak $0,038 \%$ untuk setiap 1\% kenaikan kemiringan lahan. Martono (2004) menyatakan bahwa lereng yang semakin curam dan semakin panjang akan meningkatkan besarnya erosi, jika lereng semakin curam maka kecepatan aliran permukaan meningkat sehingga daya angkutnya juga meningkat.

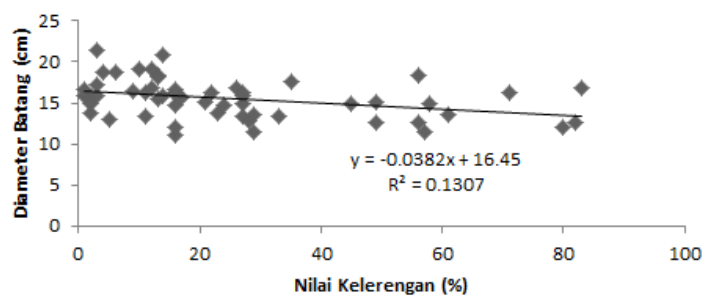

Gambar 5. Kurva nilai kelerengan dan diameter batang $(\mathrm{cm})$

Rata-rata jumlah buah pada kelas kemiringan lereng menunjukkan bahwa semakin meningkat kelerengan maka jumlah buah yang dihasilkan tanaman semakin menurun. Sekitar 24,2\% keragaman jumlah buah di lahan yang diteliti berhubungan dengan kemiringan lahan (Gambar 6). Jumlah buah cenderung berkurang sebanyak 0,86 buah untuk setiap kenaikan kelerengan $1 \%$. Pada kelerengan datar (0-8\%) sampai landai (8-15\%) jumlah buah banyak sedangkan kelerengan bergelombang, curam dan sangat curam jumlah buah tidak banyak. Hasil penelitian Pambudi \& Hermawan (2010) menunjukkan adanya penurunan TBS kelapa sawit dengan semakin meningkatnya kelerengan lahan. Lahan dengan kemiringan 0-8\% dan 8-15\% menghasilkan TBS yang secara nyata lebih tinggi dibandingkan lahan dengan kemiringan 15$30 \%$ dan $>30 \%$.

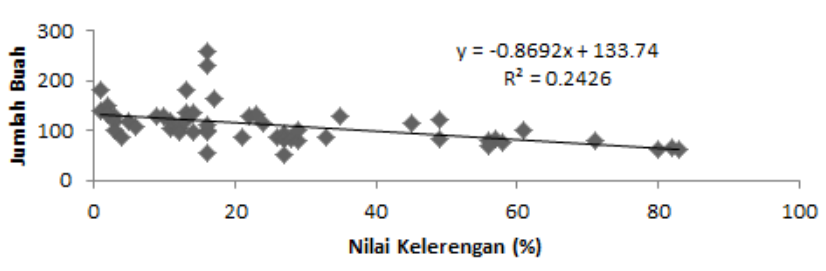

Gambar 6. Kurva nilai kelerengan dan jumlah buah

Berat buah pada kelas kemiringan lereng menunjukkan bahwa semakin besar lereng maka berat buah akan semakin menurun. Hasil analisis regresi menunjukkan bahwa sekitar 32,2\% keragaman berat buah di lahan yang diteliti dapat dijelaskan oleh nilai kelerengan. Jumlah buah cenderung turun sebanyak 124,9\% untuk setiap 1\% kenaikan kemiringan lahan. Hal ini disebabkan pada lereng yang semakin curam jumlah buah tidak terlalu banyak, maka berat buah tidak seimbang dengan jumlah buah dan pertumbuhan tanaman. Rata-rata ukuran buah jeruk Gerga yang ada di lapangan adalah 250-350 g. Berat buah jeruk lebih tinggi pada lereng datar $(0-8 \%)$ dan landai $(8-15 \%)$. Hal ini sesuai dengan hasil penelitian Fatmawaty (2006) dengan pembuatan teras secara nyata bisa mempercepat waktu muncul bunga, mempercepat waktu mun -cul buah, dan meningkatkan hara P pada daun. Menurut Arsyad (1983) pembuatan teras pada lahan miring dimaksudkan untuk memperpendek panjang lereng, mempertahankan kelembaban tanah dan air, sehingga dapat meningkatkan infiltrasi dengan demikian erosi berkurang. Berkurangnya tingkat erosi mengakibatkan unsur hara yang ada di dalam tanah dapat dimanfaatkan secara optimal oleh tanaman untuk merangsang pertumbuhan vegetatif.

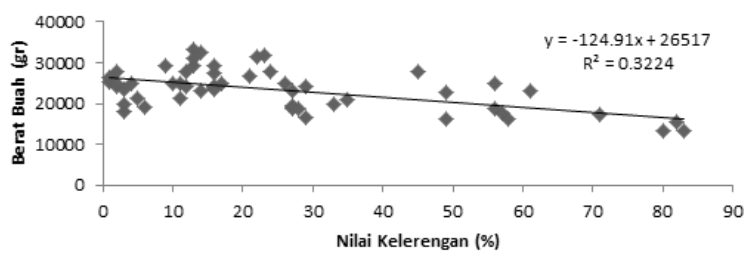

Gambar 7. Kurva nilai kelerengan (\%) dan berat buah (g)

\section{KESIMPULAN}

Hubungan kelerengan dengan sifat tanah dan penampilan tanaman yang diamati dapat dinyatakan dalam bentuk persamaan linear yang menjelaskan bahwa sifat tanah maupun penampilan hasil tanaman mengalami penurunan seiring dengan semakin tingginya tingkat kelerengan tanah 


\section{DAFTAR PUSTAKA}

Adiwilaga, A. (1985). Ilmu Usaha Tani. Fakultas Pertanian Universitas Padjajaran, Bandung.

Arsyad, S. (1983). Pengawetan Tanah dan Air. Departemen Ilmu Tanah. Fakultas Pertanian. Institut Pertanian Bogor, Bogor.

Badan Litbang Pertanian. (2005). Porspek dan Arah Pengembangan Agribisnis Jeruk. Badan Penelitian dan Pengembangan Pertanian. Kementerian Pertanian, Jakarta.

BPS. (2010). Provinsi Bengkulu Dalam Angka. Badan Pusat Statistik Provinsi Bengkulu, Bengkulu.

BPS. (2015). Data Produksi Buah-buahan. http:// bps.go.id. diakses 20 September 2015.

BPTP (Balai Pengkajian Teknologi Pertanian) Bengkulu. (2012). Pengkajian Teknologi Pembungaan dan Pembuahan Jeruk Gerga di Lebong. Bengkulu.

Draper, N.R \& Smith, H. (1966). Applied Regression Analysis. John Wiley and Sons.Inc., New York.

Djaenuddin. (2003). Petunjuk Teknis Evaluasi Lahan Untuk Komoditas Pertanian. Balai Penelitian Tanah. Pusat Penelitian dan Pengembangan Tanah dan Agroklimat. Badan Litbang Pertanian. Departemen Pertanian. Bogor.

Fatmawaty, F. (2006). Pengaruh Teras, Pupuk Kandang Dan Kapur Terhadap Pertumbuhan Vegetatif, Produktivitas dan Kualitas Buah Manggis (Garcinia mangostana L.). Skripsi. Fakultas Pertanian. IPB. Bogor.

Hermawan, B. (2004). Penetapan kadar air tanah melalui pengukuran sifat dielektrik:percobaan laboratorium pada berbagai tingkat kepadatan. Jurnal Ilmu-ilmu Pertanian Indonesia, 6(2), 6674

Ibad, I. (2009). Seleksi Tanaman F1 Jeruk (Citrus sp.) Pada Fase Pembibitan. http://elibrary.ub.ac.id/handle/ 12345678/27171. diakses 26 September 2015

Martono. (2004). Pengaruh Intensitas Hujan dan Kemiringan Lereng Terhadap Laju Kehilangan Tanah Pada Tanah Regosol Kelabu. Tesis. Universitas Diponegoro, Semarang.

Morgan, R.P.C. (1979). Soil Erosion and Conservation. Longmans. London.

Murcitro, B. G., Hermawan, B., \& Anggraeni, D. (2005). Effects of cover crops and tillage systems on soil physical properties of cogongrass land. Jurnal Ilmu-Ilmu Pertanian Indonesia, 7 (1), 44-50.
Pambudi, D.T. \& Hermawan, B. (2010). Hubungan antara beberapa karakteristik fisik lahan dan produksi kelapa sawit. Akta Agrosia, 13(1), 35-39.

Prihatman, K. (2000). Sistem Informasi Manajemen Pembangunan di Pedesaan. BAPPENAS. Jakarta.

Purnomosidhi P, Suparman, JM Roshetko \& Mulawarman. (2007). Perbanyakan dan budidaya tanaman buah-buahan: durian, mangga, jeruk, melinjo, dan sawo. Pedoman Lapang, Edisi Kedua. World Agroforestry Centre (ICRAF) dan Winrock International. Bogor, Indonesia.

Rambe, S.S.M., A. Supriyanto, K. Dinata, I. Calista, \& Honorita, B. (2012) Laporan Akhir Pengkajian Teknologi Pembungaan dan Pembuahan Jeruk Gerga di Lebong. Balai Pengkajian Teknologi Pertanian Bengkulu. Balai Besar Pengkajian dan PengembanganTeknologi Pertanian. Badan Litbang Pertanian, Bengkulu.

Rambe, S.S.M. \& Ivanti, L. (2013). Pengaruh Pemupukan dan Pemangkasan Terhadap Kualitas Buah Jeruk Gerga Lebong. Penyuluh Pertanian Madya. BPTP Bengkulu.

Sanchez-Maranon, M., Soriano, M., Delgado, G., \& Delgado, R. (2002). Soil quality in Mediterranean mountain environments. Soil Science Society of America Journal, 66(3), 948-958.

Sangadji, S. (2001). Pengaruh Iklim Tropis di Dua Ketinggian Tempat yang Berbeda Terhadap Potensi Hasil Tanaman Soba (Fagopyrum esculentum Moench). Tesis. IPB, Bogor.

Sugiharto, B. (2001). Arahan Pemanfaatan Lahan Untuk Kegiatan Permukiman Berdasarkan Analisis Kesesuaian Lahan dan Penilaian Kualitas SUB DAS, Tesis Program Magister, Institut Teknologi Bandung).

Supriyanto, A. (2011). Jeruk Rimau Gerga Lebong, Unggulan Lokal yang Siap Menuju Pasar Nasional. Balai Penelitian Tanaman Jeruk dan Buah Subtropika. http://www. balitjestro.litbang. deptan. go.id. diakses 24 September 2015

Suwantoro, B. (2010). Mengenal Jeruk Rimau Gerga Lebong Lebih Dekat. Balai Benih Hortikultura Rimbo Pengadang. Dinas Pertanian dan Ketahanan Pangan Kabupaten Lebong, Bengkulu.

Yusrial, S. N., \& Wisnubroto, S. (2004). Infiltrasi, sifat fisik tanah dan erosi pada berbagai lereng tangkapan mikro Sub DAS Kali Babon. Kabupaten Semarang. Agrosains, 17, 309-408. 